\title{
Participatory Planning of Tourist Train Station Accessibility and Creative Industry Development
}

\author{
Muhamad Muhamad*, Aneke Rahmawati \\ Master Program in Tourism Studies, Postgraduate School, \\ Universitas Gadjah Mada Yogyakarta, Indonesia \\ *Corresponding Author: drmuhammad@ugm.ac.id \\ DOI: https://doi.org/10.24922/eot.v8i1.71450
}

\section{Article Info \\ Submitted \\ November $20^{\text {th }} 2020$ \\ Accepted \\ March $18^{\text {th }} 2021$ \\ Published \\ March $31^{\text {th }} 2021$}

\begin{abstract}
Wirun tourism village, which covers an area of 265,500 ha, is an area that has its appeal in the creative industry with its strategic location which is located on the main transportation route and is traversed by bus routes that are widely used by people for transportation. There is alternative transportation in the form of Tourist Trains for the people to expand their reach but they are only able to pass by and overlook the area. The purpose of this study is to determine the process of participatory planning that has high acceptability if implemented. This is because all of the stakeholders are involved in every stage of planning policy formulation. The developed method aims to describe, explain and validate social phenomena as the object of the research by systematically creating descriptions, portrayals or paintings, as well as relationships between the observed phenomena and a process or relationship, providing a complete picture in either verbal or numerical form, presenting basic information of a relationship, creating a set of categories and classifying the research subjects. The results of this study are the concept of participatory planning in the development of the concept of reconstruction, adaptive revitalization in connecting tourist destinations with the gamelan creative industry through spatial and regional revitalization approaches.
\end{abstract}

Keywords: participatory planning, accessibility, creative industries

\section{INTRODUCTION}

The problems and challenges for tourism in Indonesia today are the lack of collaboration between the government and all stakeholders, including the role and the involvement of the community in developing tourist destinations. Some of the other issues in tourism development in Indonesia are the preservation of natural resources, the participation of the local communities, accessibility, and infrastructure in going to the destination. Another problem is that the destination as a tourist attraction is not based on a structured and documented planning concept according to official development documents. This often happens on site levels such as tourism villages and other development of tourist destinations. As such, support from various internal parties is needed, including the government, all stakeholders, and the community in de- 
veloping tourist destinations.

The existence of site-level destinations such as the Wirun tourism village, as one of the most well-known tourist villages in Sukoharjo, Central Java is because of the many tourism potentials the region has. The village, which is located in Mojolaban District, also has easy access to get to from Solo City and Karanganyar since it is only one kilometer away from Solo City, Wirun tourist village is a location visited by many local and international tourists. The tourism attraction is the fact that it is the center of the gamelan creative industry that has developed since the Dutch colonial rule. The products of the creative industry have become export commodities and many tourists visit to see how they are made and to order directly from the craftsmen.

Quoting from the opinion of several experts such as Totok Susanto (2016), the word gamelan as a creative industry comes from the Javanese word "gamel" which means hitting followed by the suffix "an" which indicates a noun. Gamelan is a collection of musical instruments that are played together which consist of Kendang, Bonang, Bonang Penerus, Demung,
Saron, Peking (Gamelan), Kenong \& Kethuk, Slenthem, Gender, Gong, Gambang, Rebab, Siter, Suling. While the main ingredients in the gamelan are metal, wood, and leather. There is a ritual performed by gamelan-making experts before making the gamelan, the gamelan-making experts in question are the makers of gamelan made from metal, namely bronze in Wirun Village, Sukoharjo Regency. Several other potentials as developing tourist attractions are as shown in the Table 1.

The determination of Wirun village as a village that has an attraction for tourists to visit and become a tourist attraction lies on the Decree of the Regent as the level 2 regional head of Sukoharjo Region Number 556/460 / IV / 1993 which was issued on April 10, 1993, which recognized Wirun Village as an agricultural, arts and culture, as well as industrial tourism destination. This makes Wirun Village to be known by the surrounding communities, including tourists. The development from 1993 experienced a period of stagnation and did not develop at all, because it did not have any development concepts and documentation. Then in 2018 of a Decree from the Regent

Table 1. The potential of Wirun Tourism Village as a tourist attraction.

\begin{tabular}{ll}
\hline Potential & Description of the Potential \\
\hline Small and & Agricultural businesses, livestock, and fisheries, Small and Medium \\
Medium & Enterprises (UKM) and home industries, labor are absorbed in various \\
Enterprises & UKM and home industries as creative industries so that they absorb a lot \\
(UKM). & $\begin{array}{l}\text { of labor: gamelan makers, tile craftsmen, furniture craftsmen, sungging } \\
\text { carving, screen printers, goyor weavers, paper puppet craftsmen. }\end{array}$
\end{tabular}

Puri Sahasra Is a place of worship that is open to all beliefs and practices of ancient Adi Pura as knowledge and practices of mannerism techniques from various tradithe Spiritual tions, as an interfaith center that still survives until today and many Center foreign and domestic tourists study and live in Wirun village to learn these spiritual materials.

Embung It is a location that stores water resources and a source of freshwater Pengantin biota which is capable of storing water reserves needed, especially during the dry season and as a source of water for irrigation.

Source: Analysis, 2020 
of Sukoharjo number 414/787 of 2018 was issued, concerning the Designation of Wirun Village, Mojolaban District as a Tourism Village.

The stakeholders who played the most role in determining the tourism village were the Sukoharjo Regency Government, the Regional Development Planning Agency (Bappeda), the Sukoharjo Regency Tourism Office assisted by the Wirun village community as the recipient village of the policy. The development of the destination to become a tourist destination, including being attractive towards tourists, must meet 3 criteria, namely:

The three requirements above according to Oka (1996) are in line with the pattern of tourism marketing objectives in destinations so that more tourists come and stay longer in the destination. The Sukoharjo Regency Government realizes that efforts to develop a tourist village in Wirun village cannot be carried out by the government alone, instead, they need the support of the related parties.
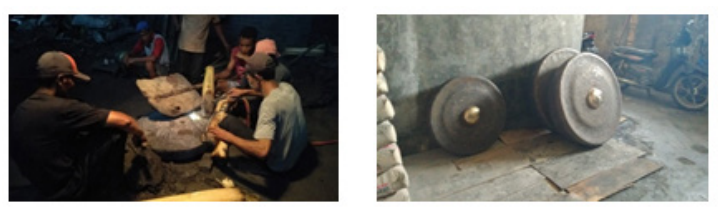

Figure 1. Gamelan produced by craftsmen in Wirun village, Mojolaban, Sukoharjo is still surviving using traditional technology.
Source: Researcher's documentation, 2020

The realization of a tourist village with a creative gamelan industry has experienced obstacles and problems. The problem is the level of participation and the role of the community in the development of tourist villages in Wirun village is still low, currently being stagnant. These problems include a) the lack of socialization of tourism villages to the community which causes a lack of public knowledge about the importance of tourism. Socialization of potential attractions in Wirun tourist village, including the active role of the Tourism Awareness Group (Pokdarwis) is less than optimal, b) lack of understanding of the village community on the importance of tourism, c) accessibility problems, especially between modes of transportation in the form of a tourist train that crosses Wirun village. A stopping point for the tourist is needed, d) the main entrance to Wirun village is needed for clarity and characteristics, e) lack of involvement of stakeholders in the development of Wirun tourist village.

As a tourism village located in Mojolaban District, it has an important role as a liaison and recipient of the creative industry. Sukoharjo Regency includes large industries including textile and pharmaceutical industries, medium-sized industries including furniture, plastics, food/ beverage and garment industries, small in-

Table 2. Requirements for the Development of Tourist Destinations to become Tourist Destinations.

\begin{tabular}{ll}
\hline Tourism Aspect & Description of Aspect \\
\hline $\begin{array}{l}\text { Something to be } \\
\text { seen for the tourists }\end{array}$ & $\begin{array}{l}\text { The destination must have a tourist attraction that is different } \\
\text { from other regions' attractions. }\end{array}$ \\
$\begin{array}{l}\text { Something to do for } \\
\text { the tourists }\end{array}$ & $\begin{array}{l}\text { The destination has activities for people who live in destinations } \\
\text { and recreational facilities that can make them stay longer at the } \\
\text { destination }\end{array}$ \\
$\begin{array}{l}\text { Something to be } \\
\text { bought by the tour- } \\
\text { ists }\end{array}$ & $\begin{array}{l}\text { This destination has the availability of shopping facilities for } \\
\text { handicrafts of people living in the destination. }\end{array}$ \\
\hline
\end{tabular}
Source: Various developed sources, 2020 
dustries including tempe, tofu, traditional herbal medicine, mushrooms, food/beverage industries The following is a table of the leading regional products of Sukoharjo Regency and the distribution table of the leading industries:

From the Table $3 \& 4$, it can be seen that the leading product in Sukoharjo Regency is processed food, followed by textiles and textile products. Meanwhile, the district that produces the most superior products is Mojolaban District with 9 kinds of leading industries in Sukoharjo Regency. The 9 types of the leading industries are: Processed Food, Textiles and Textile Products, Gamelan, Roof Tile, Alcohol, Batik, Lurik (manual loom), Brick, and Shuttlecock.

From the Table 5, it can be seen that there has been an increase in the number of companies/industries in Sukoharo Regency, which is 348 companies/small industries from 2011 to 2018 . The next increase was for medium companies/industries, namely 105 medium companies/industries. The increase also occurred in large companies/in- dustries, namely an increase of 195 companies/industries. If all of them are summed up, the total increase in all companies/industries in Sukoharjo Regency is 648 companies/industries.

The problems faced by Wirun Village have the characteristics of Panca Helix which was adopted as an operational approach to encourage innovation activities at the territorial or site level such as Wirun Village. The characteristic is particularly useful for sites with relevant knowledgebased economies, creative industries driven by innovation, all supported by consensus action by the parties concerned. In destinations at the site level where conditions are not supportive, the implementation of Panca Helix is still considered ineffective. This can occur especially in areas with poor economic growth rates, where innovation and knowledge from academics lack support from the industries, Viale and Ghiglione, (1998).

The main purpose of this research is how to revive the tourism village with involvement in planning which is supported

Table 3. Local Leading Products of Sukoharjo Regency

\begin{tabular}{lc}
\hline Product & Number of Business Units \\
\hline Textile and Textile Product & 1,107 \\
Batik & 88 \\
Lurik and Sarung Goyor (Manual loom) & 205 \\
Traditional Herbal Medicine & 120 \\
Alcohol & 123 \\
Rattan Furniture & 289 \\
Wooden Furniture & 820 \\
Guitar & 250 \\
Gamelan & 21 \\
Shuttlecock & 98 \\
Leather Crafts (Tatah Sungging and Calligraphy) & 49 \\
Processed Food & 2,206 \\
Roof Tile & 398 \\
Engraved Glass & 4 \\
Wuwung and Talang Seng (Zinc Gutter) & 124 \\
Source: Sukoharjo Regency Industry and Manpower Agency (2017) \\
http://ojs.unud.ac.id/index.php/eot
\end{tabular}


Table 4. Distribution of Leading Industries in Sukoharjo Regency

\begin{tabular}{|c|c|}
\hline Sub-district & Type of Industry \\
\hline Kartasura & $\begin{array}{l}\text { Processed Foods, Textiles and Textile Products, Engraved Glass, } \\
\text { and Crafts }\end{array}$ \\
\hline Gatak & $\begin{array}{l}\text { Processed Foods, Textiles and Textile Products, Rattan Furniture, } \\
\text { Javanese Clothing, and Crafts }\end{array}$ \\
\hline Grogol & $\begin{array}{l}\text { Processed Food, Textiles and Textile Products Engraved Glass, Gui- } \\
\text { tar, Batik, Shuttlecock and Embroidery }\end{array}$ \\
\hline Baki & $\begin{array}{l}\text { Processed Foods, Textiles and Textile Products, Engraved Glass, } \\
\text { and Shuttlecock }\end{array}$ \\
\hline Sukoharjo & $\begin{array}{l}\text { Processed Food, Textiles and Textile Products, Tatah Sungging, } \\
\text { Wooden Furniture, Batik, Woven Bamboo, and Traditional Herbal } \\
\text { Medicine }\end{array}$ \\
\hline Nguter & $\begin{array}{l}\text { Processed Foods, Textiles and Textile Products, and Traditional } \\
\text { Herbal Medicine }\end{array}$ \\
\hline Mojolaban & $\begin{array}{l}\text { Processed Food, Textiles and Textile Products, Gamelan, Roof Tile, } \\
\text { Alcohol, Batik, Lurik (manual loom), Bricks, and Shuttlecocks }\end{array}$ \\
\hline Polokarto & $\begin{array}{l}\text { Processed Foods, Textiles and Textile Products, Batik, Alcohol, and } \\
\text { Roof Tile }\end{array}$ \\
\hline Tawangsari & $\begin{array}{l}\text { Processed Foods, Textiles and Textile Products, Sarung Goyor, and } \\
\text { Batik }\end{array}$ \\
\hline Weru & $\begin{array}{l}\text { Processed Food, Textiles and Textile Products, Lurik (manual loom), } \\
\text { Batu Bata, Talang \& Wuwung Seng, Roof Tile }\end{array}$ \\
\hline Bulu & $\begin{array}{l}\text { Processed Food, Textiles and Textile Products, Bird Cages, Wooden } \\
\text { Furniture, Bags from Plastic Waste }\end{array}$ \\
\hline Bendosari & $\begin{array}{l}\text { Processed Foods, Textiles and Textile Products, Sesame Oil, and } \\
\text { Woven Bamboo }\end{array}$ \\
\hline
\end{tabular}

Source: Sukoharjo Regency Industry and Manpower Agency (2017)

Table 5. Classification of Companies/Industries in Sukoharjo Regency

\begin{tabular}{ccccc}
\hline \multirow{2}{*}{ Year } & \multicolumn{4}{c}{ Classification of Company/Industry } \\
\cline { 2 - 4 } & Small & Medium & Large & \\
\hline 2011 & 103 & 121 & 9 & 233 \\
2012 & 100 & 88 & 65 & 253 \\
2013 & 260 & 135 & 84 & 479 \\
2014 & 284 & 149 & 95 & 528 \\
2015 & 306 & 157 & 102 & 565 \\
2016 & 321 & 175 & 106 & 602 \\
2017 & 321 & 224 & 200 & 745 \\
2018 & 451 & 226 & 204 & 881 \\
\hline
\end{tabular}

Source: Central Bureau of Statistics of Sukoharjo Regency 
by efforts to connect the tourist train transportation route. The stopping point is a tourist route from the city point to the tourist village in the form of the main entrance for the tourist train line from Purwosari Station, Solo City to Wonogiri Regency. It is hoped that the route will be able to stop at the tourist village that previously existed but is now gone (demolished). It is hoped that these stopping points will facilitate the transportation route for tourists and make it easier to reach tourist destinations. As such, a participatory planning concept approach is needed in the revitalization of the area including developing the potential of the tourism village in the form of the Gamelan creative industry to become a growing and developing area, especially the resurrection of the village's creative economy.

\section{METHOD}

The developed method aims to describe, explain and validate social phenomena as the object of the research by systematically creating descriptions, portrayals or paintings, as well as relationships between the observed phenomena and a process or relationship, providing a complete picture in either verbal or numerical form, presenting basic information of a relationship, creating a set of categories and classifying the research subjects. The data collection technique is carried out by interview, to gather information about the planning process carried out by the Wirun village government. Interviews were conducted on research subjects which included key informants, namely people affected by policies and policymaking. The next technique is the observation used to measure site analysis, studying the history of the station that is no longer there, the distance of connection through mapping, conservation actions that must be taken, supporting documents, and revitalization of the area. Documentation of research implementation is carried out to document various activities and implementation of the tourist train station master plan and Focus Group Discussion (FGD), which is a data collection method commonly used in qualitative research.

\section{RESULT AND DISCUSSION}

The purpose of the focus group itself is to obtain input or information on issues that are local and specific. The resolution of this problem is determined by the other party after the information has been collected and analyzed. The implementation of focus group discussions is done with the aim of 1) so that each participant has the opportunity to speak, express opinions, and be actively involved in the discussion, (2) discussion participants come from policymakers and various elements, as presented in the Table 6:

Table 3 illustrates the concept of participatory planning involvement and participatory elements that the tourist train station plan has received attention and responses from various parties to realize the plan until now. This is in line with Carayannis and Campbell (2010) thinking of the importance of government, university and industry policies as well as civilian communities interacting intelligently, effectively, and efficiently, this approach makes the concept of participatory tourism train station planning as follows:

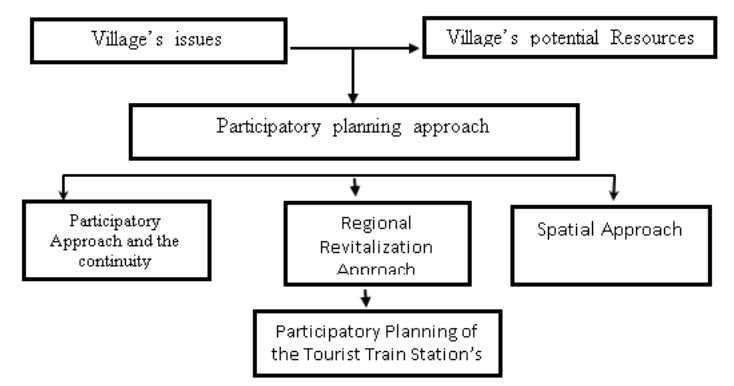

Figure 2. Theoretical framework and participatory planning concept, 2020. Source: Research analysis

\section{Spatial Approach}


Table 6. Participatory Elements and Focused Discussion Participants in the Formulation of the Master Plan for the Tourist Train Station in Wirun Village.

\begin{tabular}{|c|c|}
\hline $\begin{array}{l}\text { Focus Discussion } \\
\text { Participants and Policy } \\
\text { Makers }\end{array}$ & Functions and Authority \\
\hline $\begin{array}{l}\text { Academic elements: } \\
\text { University }\end{array}$ & $\begin{array}{l}\text { The University collaborates with the tourism village, espe- } \\
\text { cially in the mapping of the village potentials, in the devel- } \\
\text { opment scheme of the fostered villages. In 2018-2020 the } \\
\text { village government asked for cooperation with the Univer- } \\
\text { sity to send thematic Student Community Service (SCS) } \\
\text { students for up to three consecutive years (2017-2020) }\end{array}$ \\
\hline $\begin{array}{l}\text { Industrial elements. } \\
\text { PT KAI Persero }\end{array}$ & $\begin{array}{l}\text { PT KAI Persero plays an important role in determining the } \\
\text { direction of policy and support in realizing the Wirun sta- } \\
\text { tion stopping point as well as legal formal. The most impor- } \\
\text { tant direction on technical issues and the mechanism of the } \\
\text { permit process from land status and ownership status. }\end{array}$ \\
\hline $\begin{array}{l}\text { Government elements } \\
\text { Sukoharjo Regency } \\
\text { government } \\
\text { Wirun Village govern- } \\
\text { ment }\end{array}$ & $\begin{array}{l}\text { Sukoharjo District Government has a role in formulating the } \\
\text { basic framework for development in the Regional Spatial } \\
\text { Plan (RT/RW). The Wirun Village Government plays a role } \\
\text { in formulating the basic framework for rural development } \\
\text { and is the document that reflects the entire development } \\
\text { plan. }\end{array}$ \\
\hline $\begin{array}{l}\text { Community elements } \\
\text { Tourism Awareness } \\
\text { Group (Pokdarwis) }\end{array}$ & $\begin{array}{l}\text { Their most important role is the creation of a tourism board } \\
\text { with the involvement of the community in the program. }\end{array}$ \\
\hline $\begin{array}{l}\text { Media elements } \\
\text { Surat Kabar Solo }\end{array}$ & $\begin{array}{l}\text { Their most important role as a mass media is publishing } \\
\text { news and information to the public about participatory plan- } \\
\text { ning. }\end{array}$ \\
\hline
\end{tabular}

Source: Researcher's Analysis, 2020

A spatial approach is a development approach aimed at managing spatial planning, both geographically, demographically, and the village potential (Bintarto and Hadisumarno, 1991). To explore the tourism potential in Wirun village, the Wirun village government has taken a spatial approach as a guide to the basic framework for rural development and is a document that reflects the entire Wirun station master plan including developments in a rural area. This spatial approach also answers the problems and development demands needed by the village government and community in the future.

The implementation of a Focus Group
Discussion (FGD) with the stakeholders on participatory planning of the Tourist Train Station in Wirun village, it can be seen that development planning in Wirun village uses a bottom-up system, meaning that the planning process involves the entire community (Azwar, 1988). Proposals from the villagers can be submitted to the RT/RW, then it is discussed at a regular monthly meeting. The agreed-upon proposals are then brought to a village level meeting attended by representatives from the RT/RW, $\mathrm{BPD}$, and village government. 


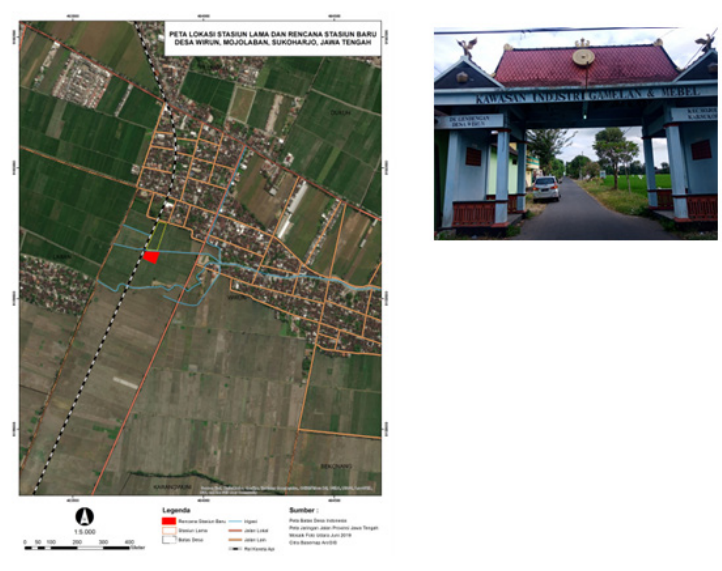

Figure 3.Village Regional Map and Tourist Train line. Source: Researcher's Analysis, 2020

\section{Participatory Approach.}

The participatory approach is based on pre-planned development planning made by the village, involving elements from universities, local government, communities, media, and industry (Panca Helix). The University plays a role in mapping the potential and existing problems and assisting in community empowerment such as Micro, Small, and Medium Enterprises, that are included in the creative industry. Local and village governments play a role in facilitating the development of tourism facilities and infrastructure, such as road infrastructure to provide accessibility. The industrial elements are working together in supporting the participatory planning of the tourist train station master plan. The role of the community, although still low in terms of participation, is to maintain the tourism environment so that it remains comfortable and safe to visit, and to increase environmental conservation so that it remains sustainable. The role of the mass media is to promote tourist objects and publishing tourism village activities to a wider audience so that the tourist village is increasingly known as the center of the creative industry.

\section{Regional Revitalization Approach}

The theoretical concept according to Alberts and Brinda (2005) stated that revitalization is an effort to revitalize an area or part of an area that was once vital/alive, but which has undergone degradation. The revitalization approach must be able to recognize and take advantage of environmental potential from several aspects including historical value, area significance, location uniqueness, and the image of the area (Danisworo and Martokusumo, 2002). The participatory planning of the Wirun tourist train station is to restore the train station building that was lost due to the aging building materials.

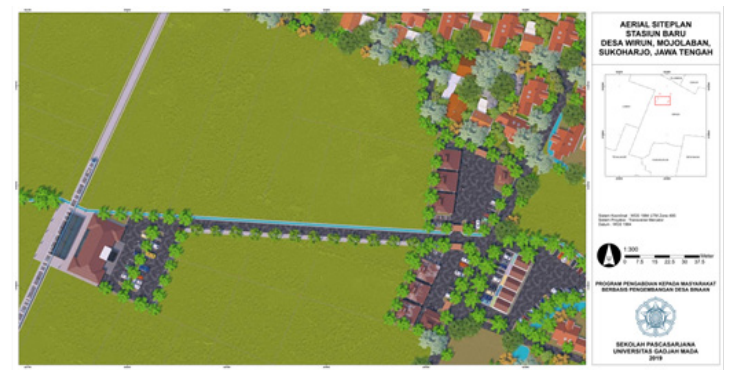

Figure 4. The concept of revitalizing the railway station area through participatory planning. Source: Researcher's Analysis, 2020

\section{Program Sustainability}

The sustainability of participatory planning and development of village potential is a sustainability program that is defined as the ability to maintain the function of the services that have been arranged in a program to continue functioning without any assistance from outside parties (Setyawan, Rahmi and Mitchell, 2000). Program sustainability is carried out continuously by emphasizing the active role of the community. The following are the sustainability program activities as a location of the development program for the fostered community in the form of creative in- 
Table 7. Participatory Plotting through Surveys and Wirun Station Data Compilation

\begin{tabular}{|c|c|c|}
\hline Location Point & Location Data & Requirements \\
\hline $\begin{array}{l}\text { Tourist train station } \\
\text { planning point }\end{array}$ & $\begin{array}{l}\text { Relatively flat land, land ownership } \\
\text { belongs to the village treasury, stra- } \\
\text { tegic location, passed by the Bathara } \\
\text { Kresna Railway to Solo and Wono- } \\
\text { giri. }\end{array}$ & $\begin{array}{l}\text { Station, ticketing room, } \\
\text { waiting room, parking } \\
\text { area, ticket room, ware- } \\
\text { house, and generator }\end{array}$ \\
\hline $\begin{array}{l}\text { Connecting lines in } \\
\text { the form of roads and } \\
\text { pedestrian paths. }\end{array}$ & $\begin{array}{l}\text { The land is relatively flat, the land is } \\
\text { owned by the village treasury, stra- } \\
\text { tegic location, vegetation paths as a } \\
\text { guide }\end{array}$ & $\begin{array}{l}400 \text { meters long con- } \\
\text { necting line to the sta- } \\
\text { tion area }\end{array}$ \\
\hline Parking Area & $\begin{array}{l}\text { Relatively flat land, the land is } \\
\text { owned by the village, strategic loca- } \\
\text { tion, capacity to park } 4 \text { wheels and } 2 \\
\text { wheels vehicles. }\end{array}$ & $\begin{array}{l}\text { a parking area and } \\
\text { village transportation } \\
\text { intermodal }\end{array}$ \\
\hline
\end{tabular}

Source: Data of the Existing Location, 2020

Table 8. Program sustainability

\begin{tabular}{|c|c|c|c|}
\hline Program Sustainability & $\begin{array}{l}\text { Sustained Pro- } \\
\text { grams/sources of } \\
\text { funding }\end{array}$ & $\begin{array}{l}\text { Program's Sup- } \\
\text { port }\end{array}$ & $\begin{array}{l}\text { Indicators of success } \\
\text { and direct impact on } \\
\text { the community }\end{array}$ \\
\hline \multicolumn{4}{|c|}{ Potential mapping in the village } \\
\hline $\begin{array}{l}\text { Planning and product } \\
\text { development (tourist } \\
\text { attractions/resources, } \\
\text { facilities, infrastructure) }\end{array}$ & $\begin{array}{l}\text { District Govern- } \\
\text { ment, District, } \\
\text { University }\end{array}$ & $\begin{array}{l}\text { District Govern- } \\
\text { ment, Village } \\
\text { Government, } \\
\text { Village Commu- } \\
\text { nity, University }\end{array}$ & $\begin{array}{l}\text { The community } \\
\text { makes programs } \\
\text { Communication with } \\
\text { PT KAI for participa- } \\
\text { tory planning }\end{array}$ \\
\hline $\begin{array}{l}\text { Planning and human } \\
\text { resource development }\end{array}$ & $\begin{array}{l}\text { District Govern- } \\
\text { ment Tourism } \\
\text { Board, University }\end{array}$ & Tourism Board & $\begin{array}{l}\text { Basic human re- } \\
\text { source development } \\
\text { training for access to } \\
\text { the central govern- } \\
\text { ment }\end{array}$ \\
\hline $\begin{array}{l}\text { Organizational/insti- } \\
\text { tutional planning and } \\
\text { development }\end{array}$ & $\begin{array}{l}\text { District Govern- } \\
\text { ment Tourism } \\
\text { Board, University }\end{array}$ & $\begin{array}{l}\text { District village } \\
\text { Government, } \\
\text { University }\end{array}$ & $\begin{array}{l}\text { Formation of respon- } \\
\text { sible administrations. }\end{array}$ \\
\hline $\begin{array}{l}\text { Planning and develop- } \\
\text { ing the Station Area } \\
\text { environmental arrange- } \\
\text { ments }\end{array}$ & $\begin{array}{l}\text { Public Works } \\
\text { Service, Tourism } \\
\text { Board, University }\end{array}$ & $\begin{array}{l}\text { Local Govern- } \\
\text { ment Village } \\
\text { Government, } \\
\text { University }\end{array}$ & $\begin{array}{l}\text { Planning program } \\
\text { documents and sup- } \\
\text { porting activities. }\end{array}$ \\
\hline $\begin{array}{l}\text { Planning and develop- } \\
\text { ment of community } \\
\text { roles and capacities }\end{array}$ & $\begin{array}{l}\text { Public Works } \\
\text { Service, Tourism } \\
\text { Board }\end{array}$ & $\begin{array}{l}\text { Local Govern- } \\
\text { ment Village } \\
\text { Government, } \\
\text { University }\end{array}$ & $\begin{array}{l}\text { The formation of } \\
\text { tourism awareness } \\
\text { group administration }\end{array}$ \\
\hline
\end{tabular}


dustries such as gamelan craftsmen, puppet craftsmen, and other traditional arts.

\section{CONCLUSION}

Planning carried out in a participatory manner is planning that is carried out through a deliberative development planning mechanism at the sub-districts, district/city level, as well as at the provincial level. Policies that are determined through a participatory process have high acceptability if implemented because all stakeholders are involved in every stage of planning policy formulation.

Revitalization is an effort to revitalize an area or part of an area that was once vital/alive, but which has undergone degradation. The revitalization approach must be able to recognize and take advantage of environmental potential from several aspects including historical value, area significance, location uniqueness, and the image of the area.The existence of the creative industry is part of something tourists must be able to see, something that tourists able to do, something that tourists able to buy so that the connection between destinations

University Elements, Industrial Elements, Government Elements, Community Elements, and Media Elements are important elements in mapping potential, identifying problems, and helping to solve problems.

\section{AKNOWLEDGEMENT}

Ministry of Research and Technology/National Research and Innovation Agency (RISTEK-BRIN). Master Program in Tourism Studies, Postgraduate School of Universitas Gadjah Mada, Yogyakarta. Universitas Gadjah Mada Directorate of Community Service, Yogyakarta.

\section{REFERENCES}

Alberts, H. C. and Brinda, M. R. (2005) 'Changing approaches to historic preservation in Quedlinburg, Germany', Urban Affairs Review, 40(3), pp. 390-401.

Azwar, S. (1988) Sikap manusia: teori dan pengukurunnya. Liberty.

Bintarto, R. and Hadisumarno, S. (1991) Metode Analisis Geografi. Jakarta: LP3S.

Carayannis, E. G. and Campbell, D. F. J. (2010) 'Triple Helix, Quadruple Helix and Quintuple Helix and how do knowledge, innovation and the environment relate to each other?: a proposed framework for a trans-disciplinary analysis of sustainable development and social ecology', International Journal of Social Ecology and Sustainable Development (IJSESD), 1(1), pp. 41-69.

Danisworo, M. and Martokusumo, W. (2002) 'Revitalisasi kawasan kota sebuah catatan dalam pengembangan dan pemanfaatan kawasan kota', Info URDI, 13 .

Oka, A. Y. (1996) 'Pengantar ilmu pariwisata', Bandung: Angkasa.

Setyawan, B., Rahmi, D. . and Mitchell, B. (2000) Pengelolaan Sumberdaya dan Lingkungan Hidup. Yogyakarta: Gadjah Mada University Press. 